\title{
Controlling Cucumber Powdery Mildew using Cow Milk and Whey under Greenhouse Conditions
}

\author{
Kamel*, S.M. (iD and Afifi, M.M.I.
}

Received: 5 October 2020 / Accepted: 10 December 2020 / Published online: 16 December 2020.

(C) Egyptian Phytopathological Society 2020

\begin{abstract}
The role of raw cow's milk and whey (40 and 50\% dilution in water) and number of sprays against cucumber powdery mildew caused by Sphaerotheca fuliginea was studied in greenhouse experiments during 2017/18 and 2018/19. As a result of number of sprays, the disease severity percentage and area under the disease progress curve (AUDPC) were affected by the number of sprays with raw milk and whey. The number of sprays played an important role in controlling powdery mildew, and significant differences have occurred among all applied sprays. Four sprays with intervals of one week was the effective treatment in reducing disease severity, AUDPC values, compared to other treatments, i.e., two and three sprays in comparison to the fungicide as well as a control treatment. Additionally, treated plants showed a significant increase in plant growth and yield parameters in case of spraying four times. Also, the activity of defense-related enzymes (catalase, peroxidase, and polyphenoloxidase) and amino acid proline was high in response to increasing the number of sprays at four times compared with untreated plants. Light and scanning electron microscopic observations showed a clear change in the morphology of S. fuliginea spores, in addition to hyphae degradation and loss the vitality of conidia as well as rupturing the content of conidia. The results obtained also indicated that cow's milk and whey dilution effectively reduced the powdery mildew signs and symptoms on infected cucumber plants at $50 \%$ with the four sprays treatment being the most effective treatment.
\end{abstract}

Key words: Cucumber, Cucumis sativus, enzyme, greenhouse, Cow milk, Sphaerotheca fuliginea, Whey

*Correspondence: Kamel, S.M.

said_kamel88@yahoo.com

\section{Said M. Kamel}

(D) https://orcid.org/0000-0001-7243-3276

Plant Pathology Research Institute, Agricultural Research Center, 12619, Giza, Egypt.

\section{Mohamed M.I. Afifi}

(iD) https://orcid.org/0000-0002-0345-4011

Soils, Water and Environment Research Institute, Agricultural Research Center, 12619, Giza, Egypt.

\section{INTRODUCTION}

Worldwide, the cultivated cucurbits under greenhouse conditions are mainly infected and damaged by powdery mildew pathogen Sphaerotheca fuliginea, which attacks leaves, stems, and even fruits. The chemical fungicides are used as the main strategy to control the fungal diseases affecting cucurbits production under commercial conditions (Kimati et al., 1997). Usage of chemical fungicides especially repeating the application times contributes to environmental pollutions and resulted in resistant populations of $S$. fuliginea to the used fungicides (McGrath, 1996). So, searching for alternatives to chemical fungicides or reducing their application times is the urgent target. In this respect, Bettiol et al. (1999) used milk, an ecofriendly product to control squash powdery mildew caused by $S$. fuliginea. So, they suggested that foliar sprays of aqueous dilutions of fresh, nonpasteurized cow's milk can be quite effective in controlling the powdery mildew on zucchini where the weekly foliar sprays using an aqueous solution of $40 \%$ milk reduced the powdery mildew disease severity by $85-90 \%$. Also, using milk with different concentrations gave a good reduction in powdery mildew disease severity and this may be attributed to its contents of fatty acids, proteins, sugars, salts, enzymes, minerals, and vitamins. In this regard, Crisp et al. (2006) suggested that management of powdery mildew on grapevine could be done through potential alternatives to synthetic fungicides such as whey, milk individually or mixed with oils or bicarbonate. Whey of raw cow milk was also used to control the powdery mildew of squash and cucumber (Bettiol et al., 2008). On the other hand, Smith et al. (2003) mentioned that the milk-based foliar sprays of pumpkin infected naturally with Sphaerotheca fuliginea, muskmelon infected with $S$. fuliginea and tomato infected with Leveillula taurica reduced the powdery mildew signs and symptoms under open field conditions. 
Also, powdery mildew disease severity on pumpkin plants was reduced by $85-90 \%$ when $40 \%$ of milk was applied as foliar sprays (Ferrandino and Smith 2007). Recently, Kamel et al. (2017) reported that whey dilutions (50 and 40\%) followed by milk dilutions (50 and 40\%) were significantly effective in reducing the foliar symptoms of cucumber powdery mildew disease severity by $43-74 \%$.

An efficient anti-oxidative system comprising of the enzymatic, as well as non-enzymatic antioxidants, is involved in scavenging or detoxification of excess ROS (Noctor et al., 2007). As for the role of antioxidant enzymatic components, i.e. catalase (CAT), peroxidase (POX), and polyphenoloxidase (PPO) play a vital role during high ROS levels, thereby and protect plants from pathogen attack (Hafez et al., 2016). Whereas non-enzymatic antioxidants include phenolics, ascorbate, glutathione, carotenoids, and tocopherols (Gill and Tuteja, 2010)

The present work was conducted to study the role of raw cow milk and whey 40 and 50\% dilutions and the number of sprays against cucumber powdery mildew caused by $S$. fuliginea under greenhouse conditions.

\section{MATERIALS AND METHODS}

\section{Plant source:}

The efficacy of cow milk and whey with two dilutions (40 and 50\%) was evaluated under greenhouse conditions to determine the best number of sprays against $S$. fuliginea the causal agent of cucumber powdery mildew compared to fungicide Topas $100 \mathrm{EC}$ (Penconazole 10.2\% W/W, Syngenta Company). In this respect, seeds of cucumber (Cucumis sativus L., Barracuda F1) batch No. 0161531598 (Seminis Company) were obtained kindly from the Horticultural Research Institute, Agricultural Research Center (ARC). Rectangular plastic trays $(5 \times 5 \times 7 \mathrm{~cm})$ were filled with autoclaved commercial potting medium (peat-based container medium, containing peat moss and vermiculite). Seedlings 30-days old of cucumber cv. Barracuda were transplanted at the rate of 10 plants per $5 \mathrm{~m}$ in a row in the greenhouse located in Sakha, Kafr El-Sheikh governorate, Egypt. Recommendations of the Ministry of Agriculture for irrigation, fertilization and weed control were applied precisely.

\section{Milk and whey preparation:}

Cow's raw fresh milk, unpasteurized and unhomogenized was obtained from Animal Research Station located in Sakha, Kafr El-Sheikh governorate, Egypt. The whey was prepared from cow's fresh milk by heating the milk at $72^{\circ} \mathrm{C}$ in a water bath for $20 \mathrm{sec}$ then transferred immediately to water bath heated at $42^{\circ} \mathrm{C}$ for $1 \mathrm{hr}$. For obtaining the gelatinous materials of the curd, rennin enzyme was added $1 \mathrm{ml} / \mathrm{L}$ milk and then incubated at $42^{\circ} \mathrm{C}$ for $3 \mathrm{hr}$. For obtaining the whey, cheesecloth was used for the filtration process of the gelatinous materials of the curd.

\section{Experimental design:}

This experiment was conducted during 2017/2018 and 2018/2019 as complete randomized blocks design. The treatments were spraying fresh milk and whey, each with two dilutions (40 and $50 \%$ ) compared to the fungicide Topas-100 EC at the ratio $0.25 \mathrm{ml} / \mathrm{L}$ and untreated control, in a greenhouse $(9 \times 40 \mathrm{~m})$. To determine the best number of sprays on controlling cucumber powdery mildew, three replicates were sprayed with each dilution of each tested substance, viz. two sprays, three sprays and four sprays treatments with one week interval. Foliar spray was carried out when the natural infection by powdery mildew was appeared on the first five true expanded leaves. Control treatment and fungicide Topas $100 \mathrm{EC}$ at ratio 0.25 $\mathrm{ml} / \mathrm{L}$. were used for comparison. For studying the effect of number of sprays on disease development, the final disease severity percentage, efficacy $\%$, area under disease progress curve (AUDPC) and $r-$ value were estimated.

\section{Disease assessment:}

Seven days after the appearance of powdery mildew symptoms, disease severity was assessed five times during the experiment, zero time, 7, 14, 21 and 28 days. The disease severity (percentage of the leaf surface covered with powdery mildew symptoms) was evaluated based on the scale of 0 to 6 according to Yan, et al., 2006, and calculated according to the equation described by Descalzo et al. (1990) as follow:

$$
\mathbf{R}=\left[\sum(\mathrm{a} \times \mathrm{b}) / \mathrm{N} \times \mathrm{K}\right] \times 100 .
$$

Where: $\mathrm{R}=$ disease severity $\%$, a =number of infected leaves rated, $\mathrm{b}=$ numerical value of each grade, $\mathrm{N}=$ total number of examined plants, $\mathrm{K}=$ the highest degree of infection in the scale. 
The efficacy of the treatments was calculated according to the following formula:

Efficacy $\%=$ $\frac{\mathrm{DS} \% \text { control }-\mathrm{DS} \% \text { treatment }}{\mathrm{DS} \% \text { control }} \times 100$

The method described by Pandey et al. (1989) was used for calculation area under disease progress curve (AUDPC) as follow:

AUDPC $=$

$$
\mathrm{D}\left[1 / 2\left(\mathrm{Y}_{1}+\mathrm{Y}_{\mathrm{K}}\right)+\mathrm{Y}_{2}+\mathrm{Y}_{3}+\ldots .+\mathrm{Y}_{(\mathrm{K}-1)}\right]
$$

Where: $\mathrm{D}=$ days between each successive two readings, $\mathrm{Y}_{1}=$ first disease record. $\mathrm{Yk}=$ last disease record.

r-value $=\frac{1}{t_{2}-t_{1}}\left(\log _{e} \frac{X_{2}}{1-X_{2}}-\log _{e} \frac{X_{1}}{1-X_{1}}\right)$

Where:

$\mathrm{X}_{1}=$ Disease severity $(\%)$ at $\mathrm{t}_{1}$ date.

$\mathrm{X}_{2}=$ Disease severity $(\%)$ at $\mathrm{t}_{2}$ date.

$\mathrm{t}_{2}-\mathrm{t}_{1}=$ Time interval in days between two observations.

\section{Growth and yield parameters:}

Plant height, chlorophyll content, fresh and dry weights were also estimated (Data are the average of 2017/2018 and 2018/2019). Plant height was taken from the base of cucumber plants to the top by centimeter unit, while chlorophyll content was measured by portable leaf chlorophyll meter (Minolta SPAD-502, Japan) to determine the greenness or relative content of leaves to analyze the photosynthetic pigments according to the method of Torres-Netto et al. (2005) in treated and untreated fully expanded cucumber leaves. Yield parameters such as number of fruits/plant, mean weight fruit $(\mathrm{g})$, weight of fruits/plant $(\mathrm{kg})$ and mean product/ greenhouse (ton) were investigated, (Data are the average of 2017/2018 and 2018/2019). Enzymes activity and proline:

For the three enzyme assays and amino acid proline, $0.5 \mathrm{~g}$ of fresh treated cucumber leaf was homogenized at $0-4^{\circ} \mathrm{C}$ in $3 \mathrm{~mL}$ of $50 \mathrm{mM}$ TRIS buffer (pH 7.8), containing $1 \mathrm{mM}$ EDTA-Na $\mathrm{Na}_{2}$ and $7.5 \%$ polyvinylpyrrolidone. The homogenates were centrifuged $\left(12,000 \mathrm{rpm}, 20 \mathrm{~min}, 4^{\circ} \mathrm{C}\right)$, the enzymes activity was determined spectrophotometrically. The measurements were carried out at $25^{\circ} \mathrm{C}$, using the model UV-160A spectrophotometer. The activity of catalase (CAT) was measured according to Aebi (1984). Peroxidase (POX) activity was measured as described by Hammerschmidt et al. (1982). Polyphenoloxidase (PPO) activity was measured according to Malik and Singh (1980). Proline was measured as described by Bates et al. (1973).

\section{Microscopic observations:}

Light microscope (Leica DM1000) examination was used to study the mode of milk and whey action on conidiophores and conidia of S. fuliginea on naturally infected cucumber leaves with powdery mildew sampled at $24 \mathrm{~h}$ after the tested treating with substances every week (5 times). Photographing by microscope was done at the Agricultural Botany Dept., Faculty of Agriculture, Kafrelsheikh University, Egypt.

For scanning electron microscope (SEM), cucumber leaves bearing lesions of powdery mildew (with and without treatment) were processed according to Harley and Fergusen (1990). Tissue pieces of $\sim 4 \mathrm{~mm}^{2}$ were fixed in 3\% glutaraldehyde in $0.2 \mathrm{M}$ phosphate buffer ( $\mathrm{pH}$ 7.2) for $24 \mathrm{~h}$ at $4^{\circ} \mathrm{C}$, followed by exposure to osmium tetraoxide $\left(1 \% \mathrm{OsO}_{4}\right)$ for $1 \mathrm{~h}$ at $25^{\circ} \mathrm{C}$. Samples were dehydrated by passing through ascending concentrations of acetone and dried till the critical point. Samples were sputter-coated with gold. The examination and photographing were done using a Jeol Scanning Electron Microscope (JSM-T.330 A) in the Central Laboratory, Faculty of Agriculture, Mansoura University, Egypt.

\section{Statistical analysis:}

All experiments were designed with complete randomized block design. WASP software (Web Agriculture Stat Package) was used for analysis of variance (ANOVA). The comparisons of means were determined by Duncan's multiple range tests, at $\mathrm{P} \leq 0.05$ (Gomez and Gomez, 1984).

\section{RESULTS}

Nowadays, the major ways of modern, safe and sustainable in agriculture depend on eco-friendly disease management strategies. Naturally infected cucumber plants by powdery mildew were foliar sprayed two, three and four times with natural compounds such as raw milk and whey in dilution of 40 and $50 \%$ compared to fungicide and control treatment. The obtained results indicated that whey and milk could be used as a curative treatment, as a result of their antifungal activities observed in these products. 


\section{1- Effect of whey on controlling cucumber} powdery mildew:

The present results show that $50 \%$ dilution of whey was very effective than $40 \%$ in reducing the disease severity percentages of cucumber powdery mildew during 2017/2018 (Fig. 1). The number of sprays was a very effective factor, as shown in Fig. (1) which indicates that spraying cucumber plants for four times with $50 \%$ whey was more effective than 2 and 3 sprays, where the recorded disease severity values were $21.7,14.3$ and $7.0 \%$ for the tested treatments, i.e., 2, 3 and 4 sprays, respectively compared to fungicide treatment which recorded $17.7,11.3$ and $4.3 \%$, respectively.
The experiment was repeated in 2018/2019 and the obtained results confirmed that diluted whey at $50 \%$ was more effective than diluted whey at $40 \%$ in reducing disease severity percentages (Fig. 2). In this respect, the number of sprays was a very effective factor in reducing infection with powdery mildew as shown in Fig. (2) where, four sprays treatment in case of diluted whey at $50 \%$ was effective in reducing disease severity $\%$ than treatments of two and three sprays, being 19.3, 13.3 and $7.3 \%$, respectively, compared to fungicide treatment which recorded 16.3, 11.0 and $5.3 \%$, respectively.

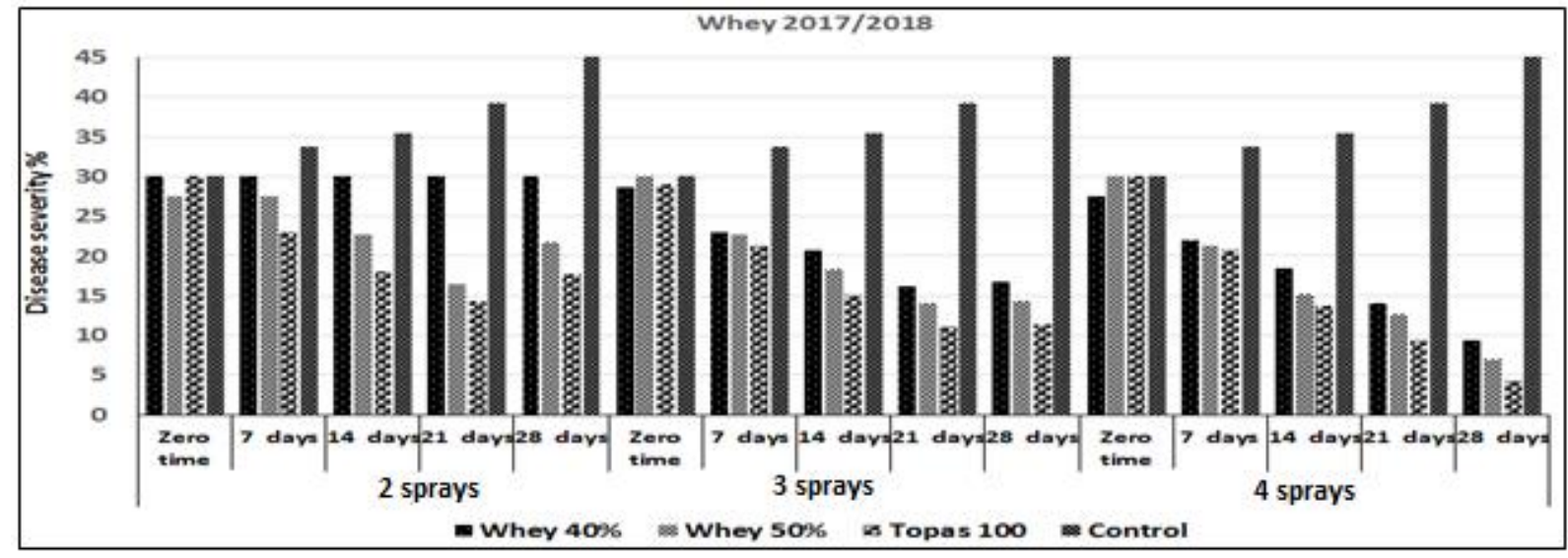

Figure (1): Effect of diluted whey at 40 and $50 \%$ and number of sprays $(2,3$ and 4$)$ on disease severity percentages during 2017/2018.

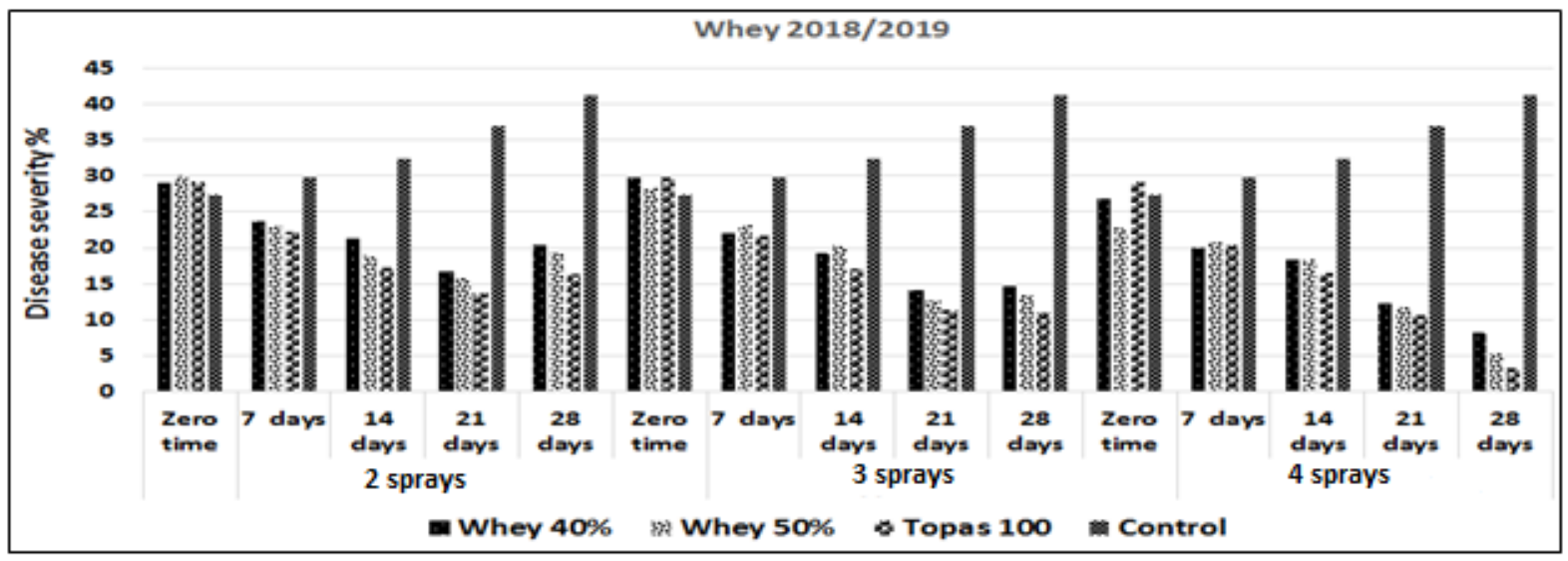

Figure (2): Effect of diluted whey at 40 and $50 \%$ and number of sprays $(2,3$ and 4$)$ on disease severity percentages during 2018/2019.

The effect of diluted whey at 40 and $50 \%$ with 2,3 and 4 sprays treatments against powdery mildew pathogen was evaluated. In this respect, the number of sprays affected positively the final disease severity percentage, efficacy $\%$, area under disease progress curve (AUDPC) and r-value
(Table, 1). The recorded final disease severity percentages due to using the effectively diluted whey at $50 \%$ with two, three and four sprays were $21.7,14.3$ and $7.0 \%$, respectively, compared to the fungicide treatment which recorded 17.7, 11.3 and $4.3 \%$, respectively, at the same conditions during 
2017/2018. Similar results were obtained during 2018/2019 (Table 1). Consequently, the recorded efficacy percentages were significantly higher with using diluted whey (50\%) for 4 sprays treatment.
Also, AUDPC values and r-value were significantly reduced by spraying cucumber plants four times with whey $50 \%$ (Table 1 ).

Table (1): Effect of whey on some disease parameters of cucumber powdery mildew caused by $S$. fuliginea during 2017/18 and 2018/19.

\begin{tabular}{cccccccccc}
\hline \multirow{2}{*}{ Treatment } & \multirow{2}{*}{$\begin{array}{c}\text { No. of } \\
\text { sprays }\end{array}$} & \multicolumn{2}{c}{$\begin{array}{c}\text { Final disease } \\
\text { severity (\%) }\end{array}$} & \multicolumn{2}{c}{ Efficacy (\%) } & \multicolumn{2}{c}{ AUDPC } & \multicolumn{2}{c}{ r-value } \\
\cline { 2 - 10 } & & $2017 / 18$ & $2018 / 19$ & $2017 / 18$ & $2018 / 19$ & $2017 / 18$ & $2018 / 19$ & $2017 / 18$ & $2018 / 19$ \\
\hline Control & - & $45.3 \mathrm{a}$ & $41.3 \mathrm{a}$ & - & - & $1023 . \mathrm{a}$ & $933.1 \mathrm{a}$ & $0.022 \mathrm{a}$ & $0.021 \mathrm{a}$ \\
\hline \multirow{2}{*}{ Whey } & 2 & $21.3 \mathrm{~b}$ & $20.3 \mathrm{~b}$ & 52.9 & 50.8 & $612.2 \mathrm{~b}$ & $604.5 \mathrm{~b}$ & $-0.015 \mathrm{~b}$ & $-0.015 \mathrm{~b}$ \\
$40 \%$ & 3 & $16.7 \mathrm{c}$ & $14.7 \mathrm{~cd}$ & 63.1 & 64.4 & $578.2 \mathrm{bc}$ & $543.9 \mathrm{c}$ & $-0.023 \mathrm{c}$ & $-0.029 \mathrm{de}$ \\
& 4 & $9.4 \mathrm{f}$ & $8.3 \mathrm{f}$ & 79.2 & 79.9 & $510.7 \mathrm{de}$ & $479.9 \mathrm{de}$ & $-0.043 \mathrm{e}$ & $-0.046 \mathrm{~g}$ \\
\hline \multirow{2}{*}{ Whey } & 2 & $21.7 \mathrm{~b}$ & $19.3 \mathrm{~b}$ & 52.1 & 53.3 & $616.7 \mathrm{~b}$ & $604.5 \mathrm{~b}$ & $-0.010 \mathrm{~b}$ & $-0.019 \mathrm{bc}$ \\
$50 \%$ & 3 & $14.3 \mathrm{~d}$ & $13.3 \mathrm{~d}$ & 68.4 & 67.8 & $540.1 \mathrm{~cd}$ & $546.0 \mathrm{c}$ & $-0.031 \mathrm{~d}$ & $-0.031 \mathrm{e}$ \\
& 4 & $7.0 \mathrm{~g}$ & $7.3 \mathrm{f}$ & 84.5 & 82.3 & $474.3 \mathrm{e}$ & $490.7 \mathrm{~d}$ & $-0.057 \mathrm{f}$ & $-0.052 \mathrm{~h}$ \\
\hline Topas 100 & 2 & $17.7 \mathrm{c}$ & $16.3 \mathrm{c}$ & 60.9 & 60.5 & $554.1 \mathrm{~cd}$ & $530.6 \mathrm{c}$ & $-0.022 \mathrm{c}$ & $-0.024 \mathrm{~cd}$ \\
fungicide & 3 & $11.3 \mathrm{e}$ & $11.0 \mathrm{e}$ & 75.1 & 73.4 & $472.2 \mathrm{e}$ & $484.1 \mathrm{~d}$ & $-0.038 \mathrm{e}$ & $-0.037 \mathrm{f}$ \\
& 4 & $4.3 \mathrm{~h}$ & $5.3 \mathrm{~g}$ & 90.5 & 87.2 & $425.9 \mathrm{f}$ & $448.7 \mathrm{e}$ & $-0.075 \mathrm{~g}$ & $-0.064 \mathrm{i}$ \\
\hline
\end{tabular}

Values in the same column followed by the same letter are not significantly differed at $P<0.05$ level.

\section{2- Effect of cow milk on controlling cucumber} powdery mildew:

Data in Fig. (3) indicate that diluted cow milk at $40,50 \%$ was more effective in inhibiting and reducing the severity of cucumber powdery mildew when the plants were sprayed weekly as mentioned before. In this respect, four sprays treatment with cow milk 50\% achieved the lowest disease severity (5.7\%) when it was applied every week followed by treatments sprayed 3 and 2 times, which recorded 11.7 and $17.3 \%$ disease severity, respectively. Topas fungicide treatment recorded the lowest percentage of disease severity, where it recorded $4.3 \%$. On the other hand, the recorded disease severity $\%$ in control treatment was $43.7 \%$ at 28 days of application.

Also, results indicate that cow milk 50\% was very effective than $40 \%$ in reducing the disease severity percentages of cucumber powdery mildew during 2017/2018 (Fig. 3).

It is clear from the obtained results (Fig, 3) that the number of sprays was a very effective factor in controlling powdery mildew on cucumber plants where spraying plants 4 times with cow milk 50\% and fungicide treatment were more effective than two and three sprays treatments in reducing disease severity percentage compared to control treatment.

The trial was repeated during 2018/2019 and the obtained results showed the same trend obtained during 2017/2018 to confirm that milk in dilution $50 \%$ was very effective than $40 \%$ in reducing the disease severity percentages (Fig. 4). Also, the number of sprays was a highly effective factor and four sprays with cow milk $50 \%$ and fungicide treatment were more effective than 2 and 3 sprays in reducing the cucumber powdery mildew disease severity compared to control treatment.

Data presented in Table (2) show the effect of number of sprays, two, three and four using cow milk 40 and $50 \%$ against cucumber powdery mildew. In this respect, all values of final disease severity percentage, efficacy $\%$, area under disease progress curve (AUDPC) and r-value were affected by the number of sprays. However, all the three tested sprays treatments reduced final disease severity, area under the disease progress curve (AUDPC) and r-value of cucumber powdery mildew compared to control treatment. In contrast, four sprays treatment achieved the highest efficacy $\%$ of controlling the disease on sprayed cucumber plants with cow milk 40 and 50\%. Also, spraying cucumber plants with cow milk 40 and $50 \%$ showed the highest reduction of AUDPC (499.3) and (460.9) during 2017/2018 and 2018/2019 and (432.7) and (427.0) AUDPC, during 2017/ 2018 and 2018/2019, respectively, followed by using three and two sprays treatment, compared to control treatment which recorded 1011.8 and 932.1 for AUDPC, respectively, during 2017/2018 and 2018/2019. However, Topas fungicide recorded the highest reduction of 
AUDPC (409.2 and 420 AUDPC, respectively, during 2017/2018 and 2018/2019) when the plants were sprayed four times. Also, the highest reduction of r-value was recorded when cucumber plants were sprayed 4 times.

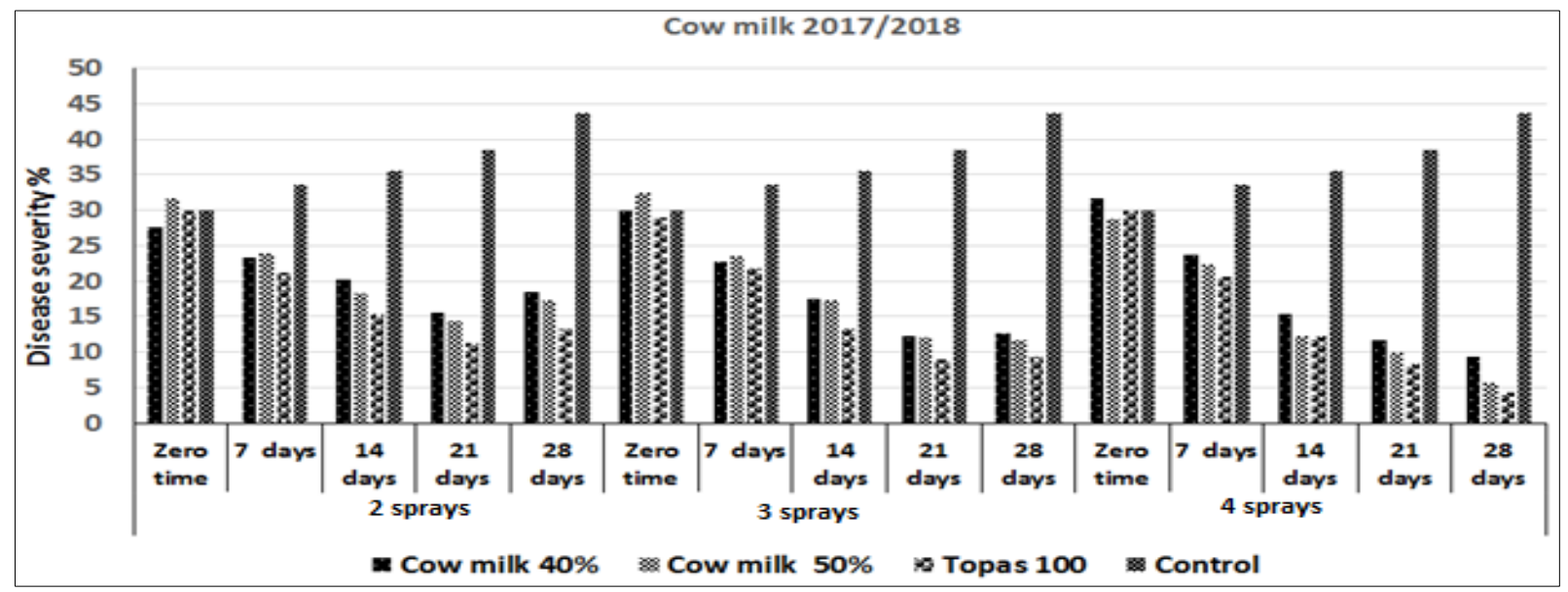

Figure (3): Effect of diluted cow milk at 40 and $50 \%$ and number of sprays (2, 3 and 4) on disease severity percentages at zero time, 7, 14, 21 and 28 days during 2017/2018.

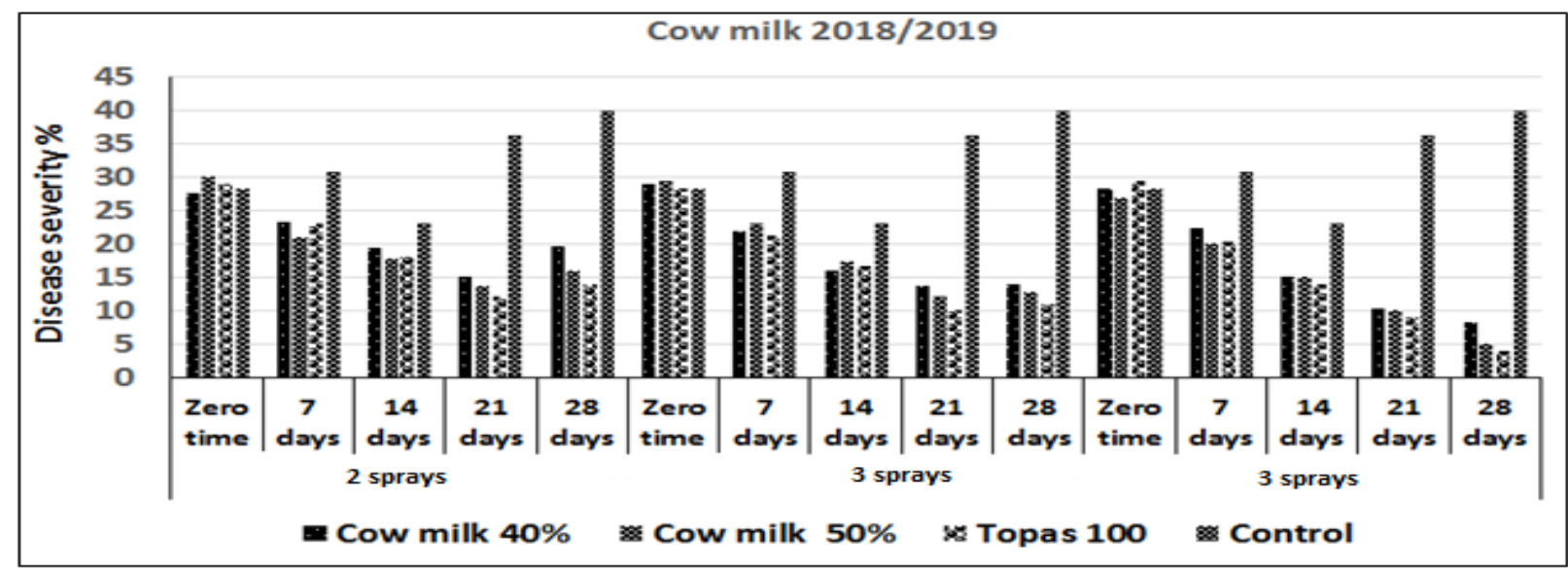

Figure (4). Effect of diluted cow milk at 40 and $50 \%$ and number of sprays (2, 3 and 4) on disease severity percentages at zero time, 7, 14, 21 and 28 days during 2018/2019.

Table (2): Effect of cow milk on some disease parameters of cucumber powdery mildew caused by $S$. fuliginea during 2017/18 and 2018/19.

\begin{tabular}{cccccccccc}
\hline \multirow{2}{*}{ Treatment } & \multirow{2}{*}{$\begin{array}{c}\text { No. of } \\
\text { sprays }\end{array}$} & \multicolumn{2}{c}{$\begin{array}{c}\text { Final disease } \\
\text { severity }(\%)\end{array}$} & \multicolumn{2}{c}{ Efficacy $(\%)$} & \multicolumn{2}{c}{ AUDPC } & \multicolumn{2}{c}{ r-value } \\
\cline { 2 - 10 } & $2017 / 18$ & $2018 / 19$ & $2017 / 18$ & $2018 / 19$ & $2017 / 18$ & $2018 / 19$ & $2017 / 18$ & $2018 / 19$ \\
\hline Control & - & $43.7 \mathrm{a}$ & $40.0 \mathrm{a}$ & - & - & $1011.8 \mathrm{a}$ & $932.1 \mathrm{a}$ & $0.019 \mathrm{a}$ & $0.017 \mathrm{a}$ \\
\hline \multirow{2}{*}{ Cow milk } & 2 & $18.5 \mathrm{~b}$ & $19.7 \mathrm{~b}$ & 57.7 & 50.8 & $574.3 \mathrm{~b}$ & $568.4 \mathrm{~b}$ & $-0.017 \mathrm{~b}$ & $-0.014 \mathrm{~b}$ \\
$40 \%$ & 3 & $12.7 \mathrm{c}$ & $14.0 \mathrm{~d}$ & 71.2 & 65.0 & $516.9 \mathrm{~cd}$ & $512.4 \mathrm{~d}$ & $-0.036 \mathrm{de}$ & $-0.030 \mathrm{~cd}$ \\
& 4 & $9.3 \mathrm{~d}$ & $8.2 \mathrm{f}$ & 78.7 & 79.5 & $499.3 \mathrm{de}$ & $460.9 \mathrm{e}$ & $-0.050 \mathrm{f}$ & $-0.049 \mathrm{f}$ \\
\hline \multirow{2}{*}{ Cow milk } & 2 & $17.3 \mathrm{~b}$ & $16.0 \mathrm{c}$ & 60.4 & 60.0 & $567.8 \mathrm{~b}$ & $527.8 \mathrm{c}$ & $-0.026 \mathrm{c}$ & $-0.027 \mathrm{c}$ \\
$50 \%$ & 3 & $11.7 \mathrm{c}$ & $12.7 \mathrm{~d}$ & 73.2 & 68.3 & $525.0 \mathrm{c}$ & $513.1 \mathrm{~d}$ & $-0.043 \mathrm{ef}$ & $-0.034 \mathrm{de}$ \\
& 4 & $5.7 \mathrm{e}$ & $5.0 \mathrm{~g}$ & 86.9 & 87.5 & $432.7 \mathrm{f}$ & $427.0 \mathrm{e}$ & $-0.063 \mathrm{~g}$ & $-0.064 \mathrm{~g}$ \\
\hline Topas 100 & 2 & $13.3 \mathrm{c}$ & $14.0 \mathrm{~d}$ & 69.6 & 65.0 & $485.4 \mathrm{e}$ & $521.5 \mathrm{~cd}$ & $-0.034 \mathrm{~d}$ & $-0.030 \mathrm{~cd}$ \\
fungicide & 3 & $9.4 \mathrm{~d}$ & $11.0 \mathrm{e}$ & 78.5 & 72.5 & $442.4 \mathrm{f}$ & $473.5 \mathrm{e}$ & $-0.045 \mathrm{f}$ & $-0.038 \mathrm{e}$ \\
& 4 & $4.3 \mathrm{e}$ & $4.0 \mathrm{~h}$ & 90.2 & 90.0 & $409.2 \mathrm{~g}$ & $420.4 \mathrm{f}$ & $-0.075 \mathrm{~h}$ & $-0.076 \mathrm{~h}$ \\
\hline
\end{tabular}

- Values in the same column followed by the same letter are not significantly differed at $P<0.5$ level. 
3- Effect of cow milk and whey on some growth parameters of treated cucumber plants:

All of plant height, chlorophyll content, fresh and dry weights were significantly affected as a result of treating cucumber plants with cow milk and whey 40 and $50 \%$ three times compared to the chemical fungicide and control treatment (Table 3). Plant height of cucumber was significantly increased when cow milk and whey 40 and 50\% were sprayed four times comparing with control treatment followed by those sprayed two and three sprays (Table 3). Interestingly, spraying cow milk and whey at $50 \%$ four times was the best treatment in increasing chlorophyll content, fresh and dry weights to be similar in their effects with those treated with chemical fungicide followed by those treated two and three sprays at the same dilution.

Table (3): Effect of cow milk and whey applications on some growth parameters of treated cucumber plants, data are the average of 2017/18 and 2018/19.

\begin{tabular}{|c|c|c|c|c|c|c|c|c|c|}
\hline \multirow{2}{*}{ Treatment } & \multirow{2}{*}{$\begin{array}{l}\text { No. of } \\
\text { sprays }\end{array}$} & \multicolumn{2}{|c|}{ Plant height $(\mathrm{cm})$} & \multicolumn{2}{|c|}{$\begin{array}{l}\text { Chlorophyll } \\
\text { (SPAD) }\end{array}$} & \multicolumn{2}{|c|}{ Fresh weight (g) } & \multicolumn{2}{|c|}{ Dry weight (g) } \\
\hline & & $\begin{array}{l}\text { Cow } \\
\text { milk }\end{array}$ & Whey & $\begin{array}{l}\text { Cow } \\
\text { milk }\end{array}$ & Whey & $\begin{array}{l}\text { Cow } \\
\text { milk }\end{array}$ & Whey & $\begin{array}{l}\text { Cow } \\
\text { milk }\end{array}$ & Whey \\
\hline Control & - & $174.7 \mathrm{f}$ & $170.3 \mathrm{f}$ & $21.3 \mathrm{e}$ & $19.8 \mathrm{f}$ & $202.1 \mathrm{~g}$ & $199.3 \mathrm{i}$ & $16.6 \mathrm{~g}$ & $15.9 \mathrm{~g}$ \\
\hline \multirow{3}{*}{$\begin{array}{l}\text { Dilution } \\
40 \%\end{array}$} & 2 & $234.3 \mathrm{e}$ & $227.4 \mathrm{e}$ & $33.5 \mathrm{~d}$ & $31.9 \mathrm{e}$ & $224.0 \mathrm{f}$ & $221.9 \mathrm{~h}$ & $19.2 \mathrm{f}$ & $18.7 \mathrm{f}$ \\
\hline & 3 & $240.2 \mathrm{de}$ & $235.5 d$ & $34.3 \mathrm{~cd}$ & $31.7 \mathrm{e}$ & $229.8 \mathrm{~d}$ & $228.1 \mathrm{f}$ & $21.8 \mathrm{de}$ & $20.2 \mathrm{e}$ \\
\hline & 4 & $250.1 b c$ & $242.3 b c$ & $36.2 \mathrm{ab}$ & $33.5 \mathrm{bcd}$ & $233.5 \mathrm{c}$ & $230.7 \mathrm{e}$ & $24.8 \mathrm{c}$ & $22.9 \mathrm{~d}$ \\
\hline \multirow{3}{*}{$\begin{array}{l}\text { Dilution } \\
50 \%\end{array}$} & 2 & $236.8 \mathrm{e}$ & $226.5 \mathrm{e}$ & $34.2 \mathrm{~cd}$ & $32.7 \mathrm{cde}$ & $226.4 \mathrm{e}$ & $223.8 \mathrm{~g}$ & $21.1 \mathrm{e}$ & $19.4 \mathrm{ef}$ \\
\hline & 3 & $244.9 \mathrm{~cd}$ & $236.3 d$ & $35.4 \mathrm{bc}$ & $33.1 \mathrm{bcd}$ & $229.9 d$ & $227.2 \mathrm{f}$ & $22.7 \mathrm{~d}$ & $20.0 \mathrm{e}$ \\
\hline & 4 & $256.0 \mathrm{ab}$ & $245.5 b$ & $37.4 \mathrm{a}$ & $34.3 \mathrm{ab}$ & $238.4 \mathrm{a}$ & $234.4 \mathrm{c}$ & $27.1 \mathrm{~b}$ & $26.7 \mathrm{~b}$ \\
\hline \multirow{3}{*}{$\begin{array}{l}\text { Topas } 100 \\
\text { fungicide }\end{array}$} & 2 & $236.0 \mathrm{e}$ & $237.1 \mathrm{~d}$ & $34.3 \mathrm{~cd}$ & $32.0 \mathrm{de}$ & $231.7 \mathrm{~cd}$ & $231.7 \mathrm{~d}$ & $23.9 \mathrm{c}$ & $24.3 c$ \\
\hline & 3 & $245.0 \mathrm{~cd}$ & $241.4 \mathrm{c}$ & $35.4 \mathrm{bc}$ & $33.7 \mathrm{bc}$ & $235.3 b$ & $236.2 b$ & $26.7 b$ & $26.8 b$ \\
\hline & 4 & $259.0 \mathrm{a}$ & $257.8 \mathrm{a}$ & $35.5 b c$ & $35.7 \mathrm{a}$ & $239.2 \mathrm{a}$ & $240.1 \mathrm{a}$ & $30.6 a$ & $31.2 \mathrm{a}$ \\
\hline
\end{tabular}

- Values in the same column followed by the same letter are not significantly differed at $P<0.05$ level.

4- Effect of cow milk and whey on some yield parameters of treated cucumber plants:

Data presented in Table (4) show that all yield parameters such as number of fruits/plant, mean weight fruit $(\mathrm{g})$, the weight of fruits/plant $(\mathrm{kg})$ and mean product/ greenhouse (ton) were investigated. Cow milk, whey at 40 or $50 \%$ dilutions and fungicide using any number of sprays significantly

Table (4): Effect of cow milk and whey on som are the average of 2017/18 and 2018/19.

\begin{tabular}{|c|c|c|c|c|c|c|c|c|c|}
\hline \multirow[t]{2}{*}{ Treatment } & \multirow{2}{*}{$\begin{array}{l}\text { No. of } \\
\text { sprays }\end{array}$} & \multicolumn{2}{|c|}{ No. of fruit/plant } & \multicolumn{2}{|c|}{$\begin{array}{l}\text { Mean weight fruit } \\
(\mathrm{g})\end{array}$} & \multicolumn{2}{|c|}{$\begin{array}{l}\text { Weight of fruit/ } \\
\text { plant }(\mathrm{kg})\end{array}$} & \multicolumn{2}{|c|}{$\begin{array}{l}\text { Mean product/ } \\
\text { greenhouse } \\
\text { (ton) }\end{array}$} \\
\hline & & $\begin{array}{l}\text { Cow } \\
\text { milk }\end{array}$ & Whey & $\begin{array}{l}\text { Cow } \\
\text { milk }\end{array}$ & Whey & $\begin{array}{l}\text { Cow } \\
\text { milk }\end{array}$ & Whey & $\begin{array}{l}\text { Cow } \\
\text { milk }\end{array}$ & Whey \\
\hline Control & - & $21.3 \mathrm{f}$ & $20.8 \mathrm{f}$ & $77.3 \mathrm{c}$ & $77.4 \mathrm{c}$ & $1.65 \mathrm{~h}$ & $1.61 \mathrm{f}$ & $1.32 \mathrm{f}$ & $1.29 \mathrm{e}$ \\
\hline \multirow{3}{*}{$\begin{array}{l}\text { Dilution } \\
40 \%\end{array}$} & 2 & $32.7 \mathrm{e}$ & $30.3 \mathrm{e}$ & $80.2 b$ & $80.2 b$ & $2.62 \mathrm{~g}$ & $2.43 \mathrm{e}$ & $2.10 \mathrm{de}$ & $1.98 \mathrm{~d}$ \\
\hline & 3 & $36.3 \mathrm{~d}$ & $34.4 \mathrm{~d}$ & $80.3 \mathrm{ab}$ & $81.4 \mathrm{ab}$ & $2.91 \mathrm{e}$ & $2.80 \mathrm{~d}$ & $2.33 \mathrm{de}$ & $2.24 \mathrm{c}$ \\
\hline & 4 & $42.3 b$ & $39.7 \mathrm{bc}$ & $81.2 \mathrm{ab}$ & $81,2 \mathrm{ab}$ & $3.43 b$ & $3.22 b c$ & $2.74 \mathrm{ab}$ & $2.58 \mathrm{~b}$ \\
\hline \multirow{3}{*}{$\begin{array}{l}\text { Dilution } \\
50 \%\end{array}$} & 2 & $33.7 \mathrm{e}$ & $31.2 \mathrm{e}$ & $81.7 \mathrm{ab}$ & $80.9 \mathrm{ab}$ & $2.75 \mathrm{f}$ & $2.52 \mathrm{e}$ & $2.20 \mathrm{e}$ & $2.02 \mathrm{~d}$ \\
\hline & 3 & $37.3 d$ & $34.3 \mathrm{~d}$ & $80.7 \mathrm{ab}$ & $82.0 \mathrm{a}$ & $3.01 \mathrm{~d}$ & $2.81 \mathrm{~d}$ & $2.41 \mathrm{~cd}$ & $2.24 c$ \\
\hline & 4 & $42.7 \mathrm{ab}$ & $40.0 \mathrm{~b}$ & $81.2 \mathrm{ab}$ & $81.5 \mathrm{ab}$ & $3.47 \mathrm{~b}$ & $3.26 \mathrm{~b}$ & $2.78 \mathrm{a}$ & $2.61 \mathrm{~b}$ \\
\hline \multirow{3}{*}{$\begin{array}{l}\text { Topas } 100 \\
\text { fungicide }\end{array}$} & 2 & $34.3 \mathrm{e}$ & $34.2 \mathrm{~d}$ & $80.2 \mathrm{~b}$ & $80.3 b$ & $2.75 \mathrm{f}$ & $2.75 d$ & $2.20 \mathrm{e}$ & $2.20 \mathrm{c}$ \\
\hline & 3 & $39.2 \mathrm{c}$ & $38.2 \mathrm{c}$ & $81.5 \mathrm{ab}$ & $81.4 \mathrm{ab}$ & $3.20 \mathrm{c}$ & $3.11 \mathrm{c}$ & $2.56 b c$ & $2.49 b$ \\
\hline & 4 & $44.3 \mathrm{a}$ & $43.8 \mathrm{a}$ & $81.8 \mathrm{a}$ & $82.0 \mathrm{a}$ & $3.62 \mathrm{a}$ & $3.59 \mathrm{a}$ & $2.89 \mathrm{a}$ & $2.87 \mathrm{a}$ \\
\hline
\end{tabular}

- Values in the same column followed by the same letter are not significantly differed at $P<0.05$ level. 


\section{5- Effect of cow milk and whey on activities of defense related enzymes in treated cucumber plants: \\ Powdery mildew is one of the biotic stresses} affecting plant parameters and plant productivity, where, it causes an increase of free radicals in a plant which cause plant acquisition self-defence through antioxidant enzymes (CAT, POX. and PPO). Data presented in Fig. (5) show that cow milk and whey have a vital role in controlling powdery mildew where they activated main plant self-defenses through antioxidant enzymes.

Dilutions of both cow milk and whey $50 \%$ and using them four times recorded the highest activities of defence-related enzymes, i.e., catalase, peroxidase and polyphenoloxidase in addition to the amino acid proline. In this respect, spraying cow milk at $50 \%$ four times caused the highest activities of catalase enzyme $\left(32.9 \mathrm{mMH}_{2} \mathrm{O}_{2} \mathrm{~g}^{-1}\right.$ FW $\mathrm{Min}^{-1}$ ) comparing with control and other treatments. Also, application whey $50 \%$ four times was more effective in increasing the activities of catalase to be $28.8 \mathrm{mM} \mathrm{H}_{2} \mathrm{O}_{2} \mathrm{~g}^{-1} \mathrm{FW} \mathrm{Min}{ }^{-1}$ than other treatments and control. Also, cow milk and whey at $50 \%$ increased the activities of peroxidase more than other treatments and control, being 1.202 and $1.121 \quad \mathrm{mMH}_{2} \mathrm{O}_{2} \quad \mathrm{~g}^{-1}$ FW $\mathrm{Min}^{-1}$, respectively, when cucumber plants were sprayed four times. Also, spraying 50\% dilution of cow milk or whey was more effective dilution in increasing the activities of polyphenoloxidase enzyme than the other dilution $(40 \%)$ and other treatments, being 0.109 and $0.100 \mu \mathrm{mol} / \mathrm{min}^{-1} \mathrm{~g}^{-1}$ (FW) with milk and whey, respectively.

On the other hand, there was a clear increment in determining activities of proline as a related defense amino acid as a result of spraying cucumber plants with cow milk or whey $50 \%$. The recorded activity values were 0.173 and $0.167 \mu$ $\mathrm{mol} / \mathrm{min}^{-1} \mathrm{~g}^{-1}(\mathrm{FW})$, respectively.

The lowest activity of the CAT, POX and PPO enzymes as well as proline amino acid was obtained when the fungicide Topas was applied in compare with the other tested treatments.

6- Microscopic observations on S. fuliginea, the causal agent of cucumber powdery mildew:

Light microscope examinations show that cow milk and whey at $50 \%$ affected the size and shape as well as caused shrinking of treated hyphae, conidiophores and conidia of S. fuliginea on naturally infected cucumber leaves with powdery mildew at 24 h post-treatment with four sprays (Fig. 6). Also, scanning electron microscope examination of the fungal structures taken from cucumber leaf surfaces treated with milk as well as whey at $50 \%$ dilution showed abnormalities and alterations in the conidia, conidiophores and hyphae of S. fuliginea compared to control treatment (Fig. 7). Moreover, twisting and plasmolysis of hyphae and conidiophores, conidial shrinking and collapsing were also observed (Fig.7. $\mathrm{B}$ and $\mathrm{C}$ ).

\section{DISCUSSION}

Through the dairy industry, elimination of whey which is a by-product of fresh milk processing is very necessary because it could be an environmental problem. Control of powdery mildew diseases infecting various crops through cheaper and safe alternatives to fungicides such as whey of fresh milk was initiated in 1999 (Bettiol, 2001). So, the main target of this research is to test both cow milk and whey by two dilutions (40 and $50 \%$ ) with two, three and four sprays treatments for controlling powdery mildew in cucumber plants. The obtained results indicated that spraying cucumber plants infected with powdery mildew, with cow milk and whey dilutions 40 and $50 \%$ four times were able to reduce disease severity percentage. Also, different dilutions of cow milk, as well as whey, gave a good reduction in powdery mildew area under disease progress curve, efficacy percentage and r-value through 2017/2018 and 2018/2019. These results are in agreement with Bettiol (2001) who reported that powdery mildew of squash could be controlled through the suppression of disease by using whey dilutions. Also, Crisp et al. (2005 and 2006) found that disease severity of powdery mildew of grapevine could be reduced through whey application. This may be due to its contents which consist of oil, fatty acids, proteins, sugar, salts, enzymes, vitamins and minerals (Stadnik and Bettiol, 2001). Also, Medeiros et al. (2006) reported that application of milk as foliar spray was reported to be participated with increasing of beneficial bacterial populations which may help in suppression process of the pathogen causing powdery mildew on cucumber and zucchini. In addition, Modler et al. (1998) and Ravensberg et al. (2006) observed that bovine milk was very effective in the control process of powdery mildew in tomato, rose, sweet pepper and cucumber because of lactoperoxidase, which known as an important factor in the anti-microbial system. 


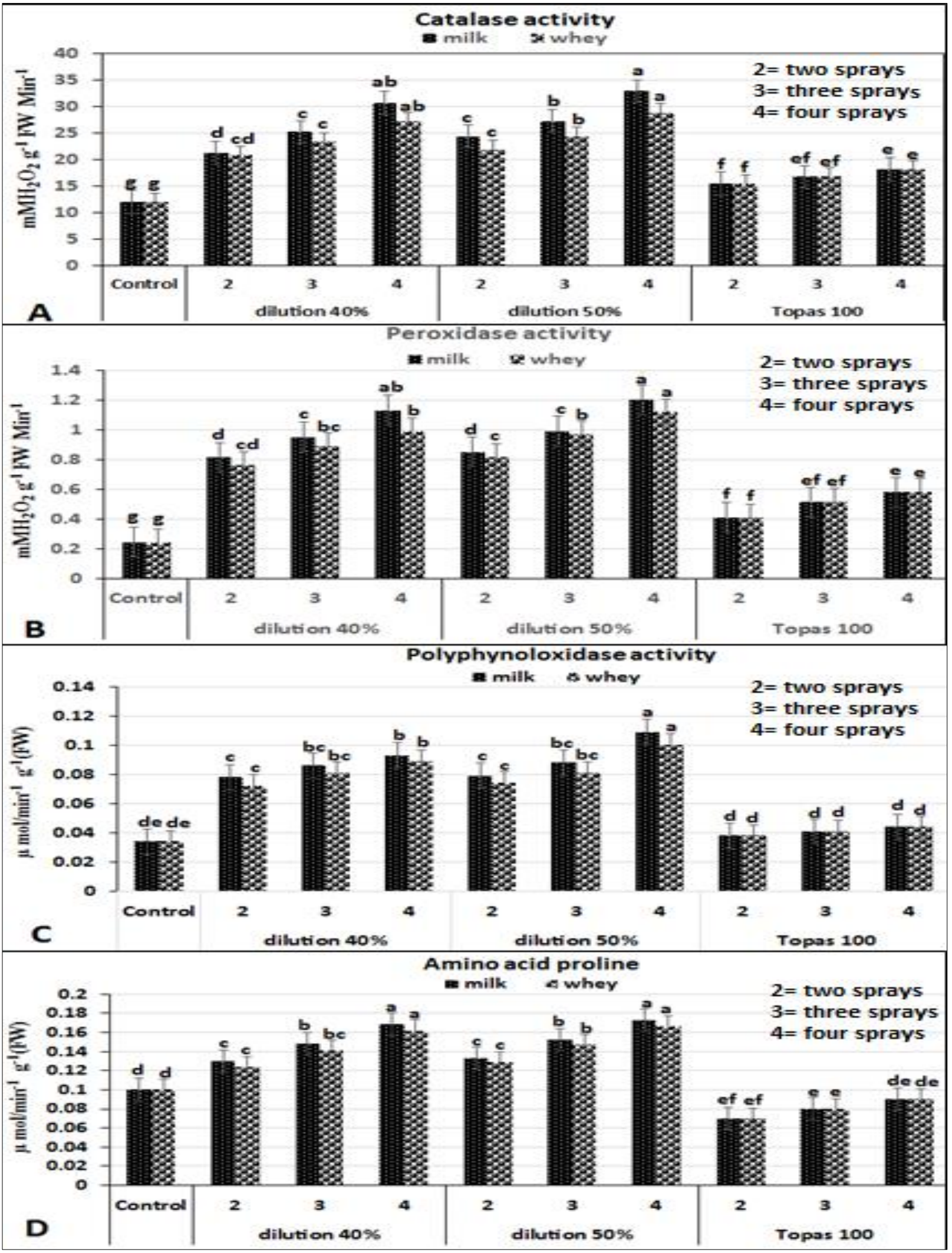

Fig. (5): Effect of cow milk and whey on activities of defense related enzymes in treated and untreated cucumber plants, $A=$ catalase, $B=$ Peroxidase and $C=$ Polyphenoloxidase activity and $D=$ Amino acid proline. 


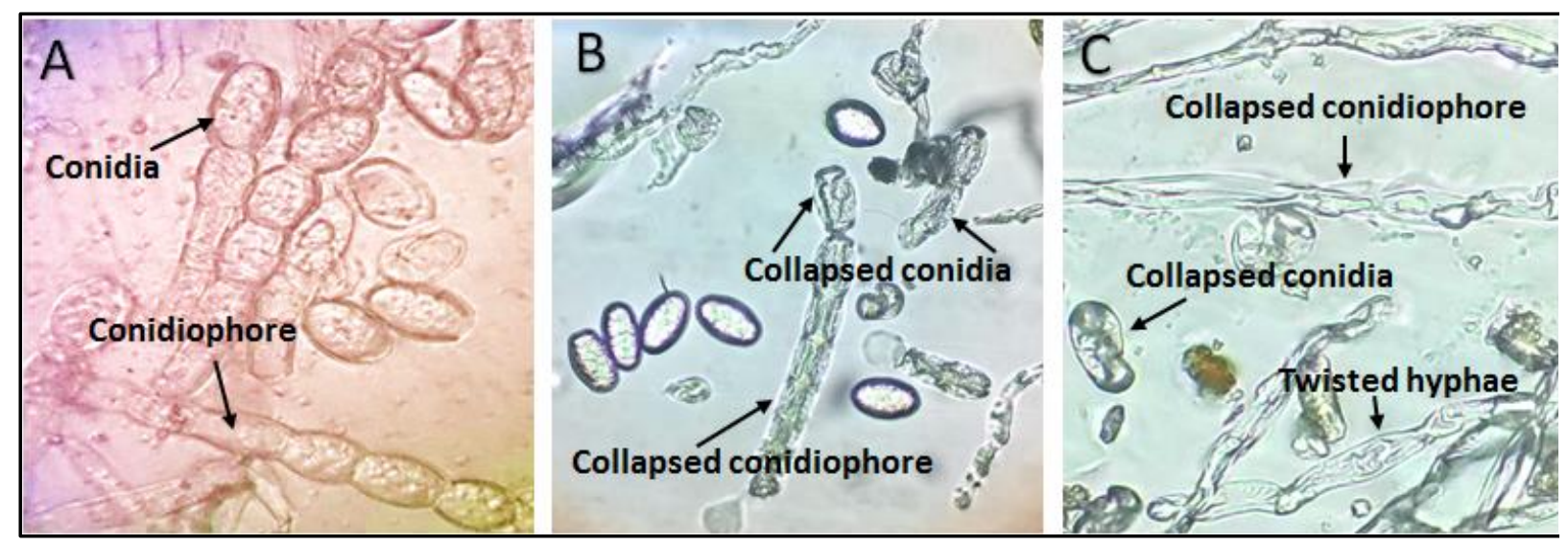

Figure (6): Light microscope observations of hyphae, conidiophores and conidia of $S$. fuliginea collected from cucumber leaf surface sprayed with cow milk or whey $50 \%$ showing, A: Untreated control with normal conidia and conidiophores (black arrows). B: cow milk 50 $\%$ and $\mathrm{C}$ : whey $50 \%$, showing twisting of hyphae and conidiophores, conidial shrinking and collapsing (black arrows), (400X).
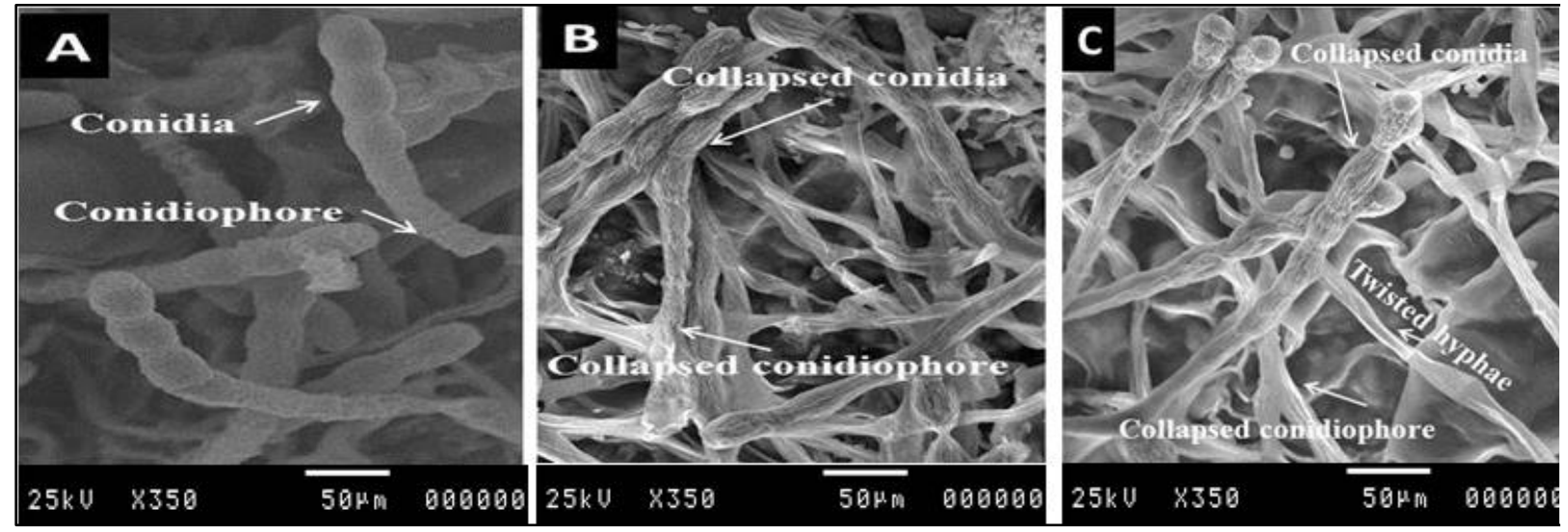

Figure (7): Scanning electron microscope observations of hyphae, conidiophores and conidia of $S$. fuliginea taken from cucumber leaf surface sprayed with cow milk or whey $50 \%$ showing, A: Untreated control with normal conidia and conidiophores (white arrows). B: cow milk $50 \%$ and $\mathrm{C}$ : whey $50 \%$, showing twisting of hyphae and conidiophores, conidial shrinking and collapsing (white arrows).

Another suggested active component of milk and whey is lactoferrin which is responsible for damage and collapse of $U$. necator conidia at $48 \mathrm{~h}$ than at $24 \mathrm{~h}$ after exposure the majority of the damage caused to hyphae after treatment with milk, whey occurred within $24 \mathrm{~h}$ of application. Also, lactoferrin, iron binding glycoprotein, binds to the membranes of various bacteria and fungi, causing damage to membranes and loss of cytoplasmic fluids (Samaranayake et al., 2001). Possibly, components of milk other than lactoferrin also caused damage to the hyphae, or the interaction with other components of milk that increased the activity of lactoferrin against hyphae
(Crisp et al., 2003). Reduction of disease severity of powdery mildew in grapevines was reported by Tzeng and DeVay (1989) to be associated with the production of free radicals when sulfur-rich amino acids, riboflavin and methionine exposure to light. The same action could be happened with milk or whey solids when influenced by solar radiations including UV and result in the production of free radicals. So the timing of application (on bright, warm days) is important factor to maximize the production of free radicals than an application on cooler and cloudy days. Crisp et al. (2006) explained that milk and its components could produce oxygen free radicals (ROS), which attacks 
the pathogen directly in the infection sites during natural sunlight. Production of ROS early during the infection process could be used by plants as weapons in defense responsive system, while continuous production might lead to susceptibility reaction and initiate of programming cell death (Ketta, 2015). the different metabolic and developmental processes that involve the interaction between ROS and hormones when high proportions ROS in plants include closing the stomata (Neill et al., 2008), programmed cell death (Bethke and Jones, 2001), control of apical root organization (Jiang and Feldman, 2003) and gaining tolerance to both biotic and abiotic stresses (Miller et al., 2008). ROS is constantly reduced/erased by plant-based antioxidant defence systems that maintain it at certain stable levels under stressful conditions (Tuteja et al., 2012).

The results indicated that the $50 \%$ dilution of both cow milk and whey, when used four times, recorded the highest activities of defence-related antioxidant enzymes, i.e., catalase, peroxidase and polyphenoloxidase which play an important role of increasing defence of plant to infection by powdery mildew. Various enzymatic antioxidants comprise of superoxide dismutase, catalase, peroxidase and polyphenoloxidase (Foyer and Noctor, 2003 and Sarhan et al., 2020). Increased activities of many antioxidant enzymes have been observed in plants to combat oxidative stress induced by various stresses and also to maintain cellular homeostasis (Almeselmani et al., 2006). Maintenance of a high antioxidant capacity to scavenge the toxic ROS has been linked to an increase in tolerance of plants to these diseases stress (Hasanuzzaman et al., 2013).

Also, our results showed that amino acid proline showed noticeable increasing with four sprays of cow milk and whey at a dilution $50 \%$. This may be attributed to milk and its derivatives content of high proline which has a role in low deleterious on plant. Proline is considered one of the self-defense tools for plant when plant is under stress. Scano et al. (2014) reported that the chemical composition analysis done by GC-MS of cow milk revealed that the aqueous fraction obtained by the extraction procedure was rich in short-chain hydroxylated carboxylic acids, such as lactic acid, succinic acid, fumaric acid, malic acid, 2-hydroxyglutaric acid, and gluconic acid; long-chain stearic and palmitic acids were also found. Among free amino acids, proline, serine, valine, glycine, alanine and glutamine were detected.
Light and scanning electron microscope examinations showed that cow milk and whey at $50 \%$ affected the size and shape as well as caused shrinking of treated hyphae, conidiophores and conidia of $S$. fuliginea collected from naturally infected cucumber leaves with powdery mildew at $24 \mathrm{~h}$ post-treatment. These results are in harmony with Kamel et al. (2017) who mentioned that microscopic observations showed abnormal shape, shrinking and collapsing of conidia with twisting and plasmolysis of conidiophores and hyphae of Sphaerotheca fuliginea when they were treated with many dilutions of both raw milk and whey. Also, Crisp et al. (2006) found that application of fresh milk or whey on Uncinula necator, which causes the powdery mildew of grapevine, caused collapse of hyphae and conidia within $24 \mathrm{~h}$ posttreatment. They hypothesized that the observed collapse of hyphae and conidia was related to increased production of free radicals. This may be due to several milk properties such as chemical and/or physical barrier could be responsible for reducing the attachment of the fungus to the cucumber leaf surfaces in addition to direct suppression of the pathogen. Slightly basic $\mathrm{pH}$ of milk could be related to the development disturbance of the fungus.

\section{CONCLUSION}

The authors recommend using cow milk and whey dilutions 40 and $50 \%$ under four sprays could be promising tools as potential alternatives to chemical fungicides against cucumber powdery mildew because of their efficacy, safety and environment eco-friendly in addition to, whey is less expensive because it considered as a waste of industrial milk process. In addition, they have a vital role and significantly effective against cucumber powdery mildew. So, we need more studies to better understand the mechanisms of cow milk and whey in controlling plant diseases.

\section{ACKNOWLEDGEMENTS}

The authors would like to thank Prof. Dr. Hammad Ketta, Agric. Botany Dept., Plant Pathology Branch, Faculty of Agriculture, Kafrelsheikh University, for his critical review of the manuscript.

\section{COMPETING INTERESTS}

The authors declare that they have no competing interests. 


\section{REFERENCES}

Aebi, H. 1984. Catalase in vitro, Methods Enzymol. 105: 121-126.

Almeselmani, M.; Deshmukh, P.S.; Sairam, R.K.; Kushwaha, S.R. and Singh, T.P. 2006. Protective role of antioxidant enzymes under high-temperature stress. Plant Sci. 171: 382388.

Bates, L.S.; Waldren, R.P. and Teare, L.D. 1973. Rapid determination of free proline for waterstress studies. Plant and Soil, 39: 205-207.

Bethke, P.C. and Jones, R.L. 2001. Cell death of barley aleurone protoplasts is mediated by reactive oxygen species. Plant J. 25: 19-29.

Bettiol, W., 2001. Soro de leite para o controle de o1 'dio (Sphaerotheca fuliginea) do pepino. Fitopatologia Brasileira 26 (Suppl.), S354. (C.F. Bettiol, et al., 2008).

Bettiol, W.; Astiarraga, B.D. and Luiz, A.J.B. 1999. Effectiveness of cow's $^{\prime}$ s milk against zucchini squash powdery mildew (Sphaerotheca fuliginea) in greenhouse conditions. Crop Prot. 18: 489-492.

Bettiol, W.; Silva, H.S.A. and Reis, R.C. 2008. Effectiveness of whey against zucchini squash and cucumber powdery mildew. Science Horticulture, 117: 82-84.

Crisp, P.; Scott, E.S. and Wicks, T.J. 2003. Mode of action of potential novel controls of grapevine powdery mildew, Uncinula necator. In 'Proceedings of the $2^{\text {nd }}$ National Organic Conference, Adelaide, Australia'. pp 133-136.

Crisp, P.; Scott, E.S. and Wicks, T.J. 2005. Evaluation of biological and novel control of grapevine powdery mildew. In: Proceedings of the $15^{\text {th }}$ Australasian Plant Pathology Society Conference Handbook, Geelong, Australia, pp. 85.

Crisp, P.; Wicks, T.J.; Troup, G. and Scott, E.S., 2006. Mode of action of milk and whey in the control of grapevine powdery mildew. Aust. Plant Pathol. 35: 487-493.

Descalzo, R.C.; Rohe, J.E. and Mauza, B. 1990. Comparative efficacy of induced resistance to selected diseases of greenhouse cucumber. Can. J. Plant Pathol., 12: 69-79.

Ferrandino, F.J. and Smith, V.L. 2007. The effect of milk-based foliar sprays on yield components of field pumpkins with powdery mildew. Crop Prot., 26(4): 657-663.
Foyer, C.H. and Noctor, G. 2003. Redox sensing and signalling associated with reactive oxygen in chloroplasts, peroxisomes and mitochondria. Physiol. Plant 119: 355-364.

Gill, S.S. and Tuteja, N. 2010. Reactive oxygen species and antioxidant machinery in abiotic stress tolerance in crop plants. Plant Physiol. Biochem. 48: 909-930.

Gomez, K.A. and Gomez A.A. 1984. Statistical Procedures for Agricultural Research. Wiley, New York. pp 680.

Hafez, Y.M.; Abdelaal, Kh.A.A.; Eid, M.E. and Mehiar, F.F. 2016. Morpho-physiological and biochemical responses of barley plants (Hordeum vulgare L.) against barley net blotch disease with application of non-traditional compounds and fungicides, Egyp. J. Biol. Pest Cont., 26: 261-268.

Hammerschmidt, R.; Nuckles, E. and Kuć, J. 1982. Association of enhanced peroxidase activity with induced systemic resistance of cucumber to Colletotrichum lagenarium. Physiol. Plant Pathol. 20: 73-82.

Harley, M.M. and Ferguson, I.K. 1990. The role of the SEM in pollen morphology and plant systematics. In: Claugher, D. (ed.) Systemic Association Special Volume. Scanning Electron Microscopy in Taxonomy and Functional Morphology, Clarendon Press, Oxford. UK. pp. 45-68.

Hasanuzzaman, M.; Nahar, K. and Fujita, M. 2013. Extreme temperatures, oxidative stress and antioxidant defense in plants, in Abiotic StressPlant Responses and Applications in Agriculture, eds K. Vahdati and C. Leslie (Rijeka: InTech), 169-205.

Jiang, K. and Feldman, L.J. 2003. Root meristem establishment and maintenanace: the role of auxin. J. Plant Growth Regul. 21: 432-440.

Kamel, S.M.; Ketta, H.A. and Emeran, A.A. 2017. Efficacy of raw cow milk and whey against cucumber powdery mildew disease caused by Sphaerotheca fuliginea (Schlecht.) Pollacci under plastic house conditions. Egyptian Journal of Biological Pest Control, 27(1): 135142.

Ketta, H.A. 2015. The role of down-regulation of antioxidant enzyme activities and reactive oxygen species accumulation in playing an essential act in soybean susceptibility to Fusarium virguliforme infection. J. of Plant 
Prot. and Pathol., Mansoura Univ., 6(10): 14391461.

Kimati, H.; Gimenes-Fernandes, N., Soave, J., Kurozawa, C., BrignaniNeto, F. and Bettiol W., 1997. Guide to Agricultural Fungicides: recommendations by culture. $2^{\text {nd }}$ ed. Grupo Paulista de Fitopatologia, Jaboticabal.

Malik, C.P. and Singh. M.B. 1980. Plant Emynology and Histoenzymology, Kalyani Publishers. Indian and Printed in Navin, Shanndara. Delhi, pp. 54-56.

McGrath, M.T. 1996. Increased resistance to triadimefon and to benomyl in Sphaerotheca fuliginea populations following fungicide usage over one season. Plant Disease. 80 (6): 633-639.

Medeiros, F.H.V.; Pinto, Z.V.; Correa, E.B. and Bettiol, W., 2006. Effect of epiphytic microorganisms on the control of zucchini hate by the application of milk. Summa Phytopathol. 32 (Suppl.), S98.

Miller, G., Shulaevb, V., and Mittlera, R. 2008. Reactive oxygen signaling and abiotic stress. Physiol. Plantarum. 133: 481-489.

Modler, H. W; Schroder, K. E. and Pratt, C. E. 1998. Inhibition of bacterial growth in whey by the activation of lactoperoxidase. Bulletin of the International Dairy Federation. 33(2): 32-46.

Neill, S.; Barros, R.; Bright, J.; Desikan, R.; Hancock, J.; Harrison, J.; Morris, P.; Ribeiro, D. and Wilson, I. 2008. Nitric oxide, stomatal closure, and abiotic stress. J. Exp. Bot. 5: 165-176.

Noctor, G.; De Paepe, R. and Foyer, C.H. 2007. Mitochondrial redox biology and homeostasis in plants. Trends Plant Sci. 12: 125-134.

Pandey, H.N.; Menon, T.C.M. and Rao, M.V. 1989. A simple formula for calculating area under disease progress curve. Rachis 8(2): 38 39.

Ravensberg, W.; Pas, R.; Weber, F. and Lier, T. 2006. The lactoperoxidase system as a novel, natural fungicide for control of powdery mildew. In: Proceeding of the IOBC/WPRS Working Group Fundamental and Practical Approaches to Increase Biocontrol Efficacy, Spa, Belgium, September 6-10, pp. 20.

Samaranayake, Y.H.; Samaranayake, L.P. Pow, E.H.N; Beena, V.T. and Yeung, K.W.S. 2001. Antifungal effects of lysozyme and lactoferrin against genetically similar, sequential Candida albicans isolates from a human immunodeficiency virus-infected southern Chinese cohort. Journal of Clinical Microbiology. 39: 3296-3302.

Sarhan, E.A.D.; Abd-Elsyed, M.H.F. and Ebrahiem, A.M.Y. 2020. Biological control of cucumber powdery mildew (Podosphaera xanthii) (Castagne) under greenhouse conditions. Egyptian Journal of Biological Pest Control. 30:65.

Scano, P.; Murgia, A.; PirisiFilippo, M. and Caboni, P. 2014. A gas chromatography-mass spectrometry-based metabolomic approach for the characterization of goat milk compared with cow milk. J. Dairy Sci. 97: 6057-6066.

Smith, V.L.; Ferrandino, F.J. and Cecarelli, R. 2003. Evaluation of milk and lactose as foliar sprays for control of powdery mildew of tomato, 2002. Biological and cultural tests for control of plant diseases (online.) Report 18: C5. doi:10.1094/BC16. The American Phytopathological Society, St. Paul, MN, USA.

Stadnik, M.J. and Bettiol, W. 2001. Spraying with milk stimulates the phylloplane microflora and reduces the severity of cucumber. Summa Phytopathol. 27: 109.

Torres-Netto, A.; Campostrini, E.; Oliveira, J. G. and Smith, R.E.B. 2005. Photosynthetic pigments, nitrogen, chlorophyll a fluorescence and SPAD-502 readings in coffee leaves. Scientia Horticulturae, 104(2): 199-209.

Tuteja, N.; Tiburcio, A.F.; Gill, S.S. and Tuteja, R. 2012. Improving Crop Resistance to Abiotic Stress, $1^{\text {st }}$ Edn. New Hamsphire: Wiley-VCH Verlag GmbH \& Co. KGaA. 1534 Pp.

Tzeng, D.D. and DeVay, J.E. 1989. Biocidal activity of mixtures of methionine and riboflavin against plant pathogenic fungi and bacteria and possible modes of action. Mycologia 81: 402-412.

Yan, Z.; Dolstra, O.; Prins, T.W.; Stam, P. and Visser, P. B. (2006). Assessment of Partial Resistance to Powdery Mildew (Podosphaera pannosa) in a Tetraploid Rose Population Using a Spore-suspension Inoculation Method. European Journal of Plant Pathology. 114(3): 301-308. 